\title{
DIGITIZING CULTURAL HERITAGE: EVIDENCE FROM ITALIAN MUSEUMS
}

\author{
Enrico Cori ${ }^{24}$ \\ Fabio Fraticelli ${ }^{25}$
}

https://doi.org/10.31410/itema.2018.65

\begin{abstract}
This paper aims to shed light on the link between digitization processes and competitive strategies in Italian museums. It is also addressed to understand how digital skills, held by the museum, do affect the organization's capability to match technological innovation and strategy.

In line with the exploratory nature of research, we have adopted the multi-case study approach. Three of the main Italian museums, selected through a convenient sampling, which considers the historical-architectural importance of the site and the collections housed in it, have been investigated through semi-structured interviews and document analysis.

Cases show how digitization processes are mainly driven by museums' accessibility to technical skills, as well as by the novelty character of digital innovations available. This often brings to underestimate the required alignment between digital contents, digital skills held by the cultural organizations, and types of users.

We believe that our research can contribute to a clear acknowledgement of issues concerning the digitization process by managers of the Italian museums, hence leading to adoption choices that keep into account strategic and organizational aspects, besides the technical ones.
\end{abstract}

Keywords: Digitization, digital skills, cultural heritage, alignment technology-strategy

\section{INTRODUCTION}

$\mathrm{T}$ here is a widespread awareness that cultural organizations can benefit in many ways from the adoption of digital technologies. Collection, conservation and access to the cultural heritage in novel, accessible and attractive ways demand for digitizing museums, as well as for designing methodologies to represent, manage and exploit cultural heritage data at different levels. The major Italian cultural organizations are currently engaged in choices regarding the adoption of digital technologies. However, either the literature or the empirical evidence suggest that these choices are not always the result of a clear perception and of a careful reflection about opportunities and limitations linked with the adoption of digital artifacts and devices.

Through a multi-case analysis, our paper aims to shed light on the link between digitization processes and competitive strategies in museums, in logic of reciprocal adequacy. We wonder how digital skills, held by the cultural organizations, do affect the organization's capability to align technological innovation and strategy in Italian museums.

\footnotetext{
${ }^{24}$ Department of Management, Università Politecnica delle Marche, piazzale Martelli 8, 60121 Ancona (Italy)

${ }^{25}$ Department of Management, Università Politecnica delle Marche, piazzale Martelli 8, 60121 Ancona (Italy)
} 
In the following paragraph we briefly illustrate the theoretical background; in section 3 we outline the research objectives and methodology; in section 4 we present the results of our analysis; and lastly, in section 5 we debate about such findings and draw some conclusions.

\section{THEORETICAL BACKGROUND}

The general framework of reference is constituted by the relationships that exist between the firm's strategic choices, the digitization processes, and the development of digital skills. The literature review has been circumscribed to the analysis of these relationships in museums, as well as to the identification of some possible classifications and taxonomies, related to competitive strategies, technologies, as well as to the so-called "digital skills" within cultural organizations.

Research on the processes of digitization of cultural heritage, and in particular of the museums' collections, has initially privileged the analysis of technologies for the preservation of works of art, and for their remote fruition (through the Internet), and then moved on the role and the impact of digital technologies for on-site fruition. To date, two themes still seem to us insufficiently investigated in the literature: that of the relationship between choices relating to technology and the market orientation of museum institutions; as well as the question of the adequacy of digital skills and the connected degree of technology acceptance.

As regards the first issue, references to the necessary alignment between the choices of technology adoption and the market strategies of the museums are sporadic [1] - [2] - [3]. Much of the research considers the introduction of digital technologies in museums as an independent variable, from which implications on organizational strategy, as well as on roles and skills, may arise. In other studies, the analysis of the digitization process leads to the identification of alternative digital approaches [4] - [5].

The topic of digital skills, on the contrary, is much more debated, but issues concerning technology acceptance are often neglected. Studies on this topic are mainly concerned with the identification of some possible classification criteria; otherwise they focus on the opportunities associated with the emergence of new roles and the evolution of existing roles within cultural organizations [6].

In short, in our opinion the main gaps in the literature can be traced a) in the almost total absence of a debate about the relationship between the role of digital technologies and market strategies; b) in the lack of attention to the question of technology acceptance, both on the side of museum employees and on the users' side. A deepening in these two fields of research seems really desirable; in order to support museum organizations to pursue adequate levels of efficiency and effectiveness in the digitization processes underway.

\section{RESEARCH OBJECTIVES, METHODOLOGY, AND DATA COLLECTION}

The first aim of our research was to assess the coherence between digital technologies in use and the competitive strategy pursued by the museum. Besides, we wanted to understand how digital skills, held by the museum, do affect the organization's capability to match technological innovation and strategy.

In line with the exploratory nature of research, we have adopted the multi-case study approach, in the logic of replication and of analytical generalization [7] - [8] - [9]. Indeed, the multi-case 
method makes it possible to highlight a variety of situations, even diverging from one another, with the ultimate aim of contributing to the elaboration of an explanatory theory.

The sample has been built in the following way: starting with the case of Palazzo Ducale di Urbino, we added two more cases (Palazzo Ducale di Mantova, La Venaria Reale di Torino), in order to diversify the sample, according to some parameters (ownership, yearly number of visitors, characteristics of the hosted collections). The museums have been selected following the criteria which consider the historical-architectural importance of the site and the collections housed in it. The choice to select a sample consisting of art collections hosted in ancient palaces, castles, or villas is linked to the belief that this combination extols the opportunities inherent in the digital technologies for on-site fruition (e.g. virtual/augmented reality devices). The main data relating to each museum are summed up in Table 1, below.

Table 1: The sample investigated

\begin{tabular}{l|c|c|c|c|c}
\hline \multicolumn{1}{c|}{ Museum } & Place & $\begin{array}{c}\text { Year of } \\
\text { foundation }\end{array}$ & Ownership & $\begin{array}{c}\text { Visitors } \\
(2017)\end{array}$ & $\begin{array}{c}\text { Type of } \\
\text { heritage }\end{array}$ \\
\hline $\begin{array}{l}\text { National Gallery of } \\
\text { the Marche at } \\
\text { Palazzo Ducale }\end{array}$ & Urbino & 1912 & $\begin{array}{c}\text { Public } \\
\text { (governmen } \\
\text { t) }\end{array}$ & 164.000 & $\begin{array}{c}\text { Renaissance } \\
\text { painting }\end{array}$ \\
\hline $\begin{array}{l}\text { Museums at Palazzo } \\
\text { Ducale }\end{array}$ & Mantova & 1881 & $\begin{array}{c}\text { Public } \\
\text { (governmen } \\
\text { t) }\end{array}$ & 323.000 & $\begin{array}{c}\text { Thematic } \\
\text { exhibitions }\end{array}$ \\
\hline La Venaria Reale & Torino & 2008 & $\begin{array}{c}\text { Public- } \\
\text { private } \\
\text { network }\end{array}$ & 1.049 .000 & $\begin{array}{c}\text { Paintings and } \\
\text { sculptures from } \\
\text { the } 15^{\text {th }} \text { to the } \\
17^{\text {th }} \text { century. } \\
\text { Thematic } \\
\text { exhibitions }\end{array}$ \\
\hline
\end{tabular}

The research was carried out by using both primary and secondary data. Primary data was collected through semi-structured interviews addressed to the general managers of the museums. Secondary data consisted of documents provided by the management itself and/or collected by the authors, such as website content, press releases, and so on. Interviews were performed in the period may-november 2018, either at the office of the manager or by telephone. They have lasted from thirty minutes to an hour and followed a precompiled track. However, we left managers free to investigate further points. Three main questions were posed about the following issues: type of market strategy pursued by the museum; type of digital technologies/devices in use and reasons that has pushed museums to their adoption; range of digital skills held by managers or employees in the museum.

As regards market strategies, we integrated the taxonomy proposed by [10] between mass, segmentation, or niche market strategies, and that suggested in [11], who distinguish between audience broadening, diversifying, or deepening; where the first refers to the reach of a larger share of the potential audiences, the second to the attraction of new groups of users, and the third to make the current audience more involved. As regards digital technologies, the taxonomy proposed in [12] and the distinction by [13] between remote fruition technologies (e.g.: website, social networks, multimedia, database) and on-site fruition technologies (e.g.: info-points, touch-screens, VR/AR devices) was used. Lastly, we distinguished between technical digital skills (held by the roles involved in designing and programming activities of IT solutions) and applied digital skills (ability to use software and devices by the decision 
makers and the employees involved in routinary tasks), following the distinction proposed in [14].

\section{FINDINGS}

The case of La Venaria Reale (Turin) highlights a market strategy that is clearly oriented at deepening the audience. This orientation may have been suggested by the awareness of having to consolidate relations with the audience, after a phase of marked growth in the number of visitors. The management is strongly committed in finding new and profitable ways to increase customers' loyalty, by introducing on-site technologies that can foster a greater user-heritage interaction (i.e., through the introduction of chatbots technology for a simulation of a dialogue between visitors and characters depicted in the paintings); on the contrary, the enlargement of the visitors' base does not seem to be a priority. With regard to implementation methods of the on-site technologies, the management is intended to mainly rely on internal and applied digital skills. Indeed, the analysis shows that the museum has a rather high level of applied skills that are widespread among employees. At the same time, some employees have also (some) technical skills, meaning that they are capable to intercept the cutting edge of the "digital transformation potential" and - most important - to understand its applicability in the specific context in which they operate. The access to external technical skills is an option which, however, in the perspective of the management, should stay residual.

As regards the case of Museums at Palazzo Ducale in Mantova, a broadening strategy is quite clearly recognizable, so the aim is to increase the number of visitors within each customer segment. This orientation seems to be coherent in the light of the unsatisfying performance registered in the last few years. Technical skills, even those required for the ordinary maintenance, are only accessed through external suppliers, since they are not available inside the museum; however, suppliers' involvement has been significantly reduced over time, not only for the scarcity of funds, but even due to the fact that they do not guarantee the necessary timeliness of intervention. For this reason, the only one interactive on-site device that had been installed in the museum a few years ago is currently not operating. As regards applied digital skills, some kind of them are directly held by the management. In terms of support to the market strategy, those skills are mainly used to enforce and to monitor the presence on social media (as well as the website update). No employee is specifically dedicated to digital communication, but the manager's assistant is responsible for carrying out this task, along with others. In this case, the lack for technical skills seems to be the main reason why the general manager is oriented at squeezing as far as possible the internal applied skills, while integrating them with eventual contributions from external suppliers. Their focus will therefore be on technologies that can foster the remote fruition of the heritage, mainly via social media.

Finally, the case of the National Gallery of the Marche (Urbino) highlights a market strategy that is clearly oriented at audience broadening: the management is strongly committed in finding new ways to reach more visitors in the market segments that are currently addressed via targeted offerings (schools, tourist groups,...). The museum at Palazzo Ducale of Urbino has developed up to now few digital skills. These are mainly referred to software programs currently in use to perform administrative tasks, as well as to update the website and the official social media channels. Recently, a partnership with academic researchers stimulated the interest of the management in developing technologies that can foster both the remote and - even more - the on-site fruition (VR/AR devices, building information modeling, and so on...). The manager's intention is that to exploit those technologies to reach a wider audience, as well as to deepen the relation with the current audience. Once these solutions will be available, the 
museum's management plans to rely on external specialists for updating and maintenance, so bypassing the need of developing idiosyncratic skills internally.

\section{DISCUSSION AND CONCLUSION}

The joint analysis of the three cases highlights some similarities but also some differences as regards the features of the respective digitizing paths. Some approaches show a stronger awareness then others, as regards the need to align the market orientation, the availability of skills, and the type of fruition technologies. In particular, the more confident the managers are with the opportunity to get technical expertise, the more attracted they are about the adoption of on-site digital applications/devices that are designed to make the visit experience more spectacular. This, regardless the fact that there is any clear evidence that these technologies will sustain the market strategy. Museums that are not confident to access to technical skills focus on digital communication when they want to enlarge the audience base; instead, they focus on the variety and the quality of the on-site digital services in order to improve the overall visit experience. An overall reading of the three cases leads us to confirm this dynamic. In fact, while Museums at Palazzo Ducale in Mantova are turning to technologies mainly oriented to external communication, after having experienced the difficulties of using an on-site technology, the National Gallery of Urbino is evaluating the opportunity to go in the opposite direction, although there is no evidence that this shift will support the implementation of the strategy. Therefore, we believe that the (perceived) accessibility to technical skills, and not the market strategy, is a common driver for the choice between on-site or remote fruition technologies.

This paper represents only a first attempt in understanding the phenomenon of digitization in the Italian museums: the low number of cases analyzed is a clear limitation to its significance; hence, the next step of our research will pursue two different aims: a) the widening of the sample, and b) the increase of heterogeneity within the sample itself. A further limitation concerns the short period of observation, whereas the ongoing process of digitization should benefit for a prolonged observation, in the logic of a longitudinal research.

Despite the above mentioned limitations, we believe that our research is able to shed new light on the processes of digitizing that cultural heritage organizations are currently experiencing. On the one hand, evidence from the three museums enforces our initial assumption and outlines the need of a better alignment between the choices of fruition technologies adoption, and the market orientation. On the other hand, the results of the on-field analysis have provided some notable insights in order to understand how the accessibility to digital skills drives decisionmaking process regarding the deployment of technologies that are more or less suitable to support the market strategy pursued by the museums.

\section{REFERENCES}

[1] Bertacchini, E., \& Morando, F. (2013). "The future of museums in the digital age: New models for access to and use of digital collections". International Journal of Arts Management, vol. 15, n. 2, pp. 60-72.

[2] Kane, G. C., Palmer, D., Phillips, A. N., Kiron, D., \& Buckley, N. (2015). "Strategy, not technology, drives digital transformation". MIT Sloan Management Review and Deloitte University Press, vol. 14, pp. 1-25.

[3] Solima, L., \& Minguzzi, A. (2015). "Innovare il rapporto tra musei, visitatori ed utenti attraverso le relazioni digitali". Economia e diritto del terziario, n. 1, pp. 41-61. 
[4] Gombault, A., Allal-Chérif, O., \& Décamps, A. (2016). "ICT adoption in heritage organizations: Crossing the chasm". Journal of Business Research, vol. 69, n. 11, pp. 5135 5140.

[5] Dewdney, A. (2018). "What Is the current fascination with VR on the part of museums and art galleries?" Contemporary Art Society Annual Conference: The Virtual in Museums: Hot Medium?

[6] Parry, R., Eikhof, D. R., Barnes, S. A., \& Kispeter, E. (2018). "Development, supply, deployment, demand: Balancing the museum digital skills ecosystem". First findings of the 'One by One' national digital literacy project. Museums and the Web. https://mw18.mwconf.org/paper/development-supply-deployment-demand-balancingthe-museum-digital-skills-ecosystem-first-findings-of-the-one-by-one-national-digitalliteracy-project/.

[7] Eisenhardt, K. M. (1989). "Building theories from case study research", Academy of Management Review, vol. 14, n. 4, pp. 532-550.

[8] Eisenhardt, K.M., \& Graebner, M.E. (2007). "Theory Building from Cases: Opportunities and Challenges", Academy of Management Journal, vol. 50, n. 1, pp. 25-32.

[9] Yin, R. K. (2009). Case Study Research. Design and Methods, Second Edition, Thousand Oaks, CA: Sage Publications.

[10] Kotler, N. G., Kotler, P., \& Kotler, W. I. (2008). Museum marketing and strategy: designing missions, building audiences, generating revenue and resources. John Wiley \& Sons.

[11] Bakhshi, H. \& Throsby, D. (2012). "New technologies in cultural institutions: theory, evidence and policy implications", International Journal of Cultural Policy, vol. 18, n. 2, pp. 205-222.

[12] Styliani, S., Fotis, L., Kostas, K., \& Petros, P. (2009). "Virtual museums, a survey and some issues for consideration". Journal of cultural Heritage, vol. 10, n. 4, pp. 520-528.

[13] Bonacini, E. (2011). Nuove tecnologie per la fruizione e valorizzazione del patrimonio culturale. Roma, Aracne.

[14] AICA \& Assintel (2017). Osservatorio delle competenze digitali. https://www.agid.gov.it/sites/default/files/repository_files/osservatorio_competenze_digi tali_2017.pdf. 